\title{
PAPERS
}

\section{Cholecystokinin in transient lower oesophageal sphincter relaxation due to gastric distension in humans}

\author{
J Boulant, S Mathieu, M D'Amato, A Abergel, M Dapoigny, G Bommelaer
}

\begin{abstract}
Background and aims-Transient lower oesophageal sphincter relaxations (TLOSRs) has been found to be the main mechanism of gastro-oesophageal reflux. In dogs, cholecystokinin (CCK) is involved in their occurrence. The aim was to evaluate the role of endogenous and exogenous CCK in the occurrence of TLOSRs induced by gastric distension at constant pressure in humans.

Methods-Ten healthy volunteers were studied. Lower oesophageal sphincter pressure was monitored with a sleeve device and gastric distension was performed via an intragastric bag monitored by a barostat. During distensions, saline, CCK (30 $\mathrm{ng} / \mathrm{kg} / \mathrm{h}$ ) or the CCK-A receptor antagonist loxiglumide $(10 \mathrm{mg} / \mathrm{kg} / \mathrm{h})$ was perfused in a random double blind order.

Results-There was no significant difference between the number of TLOSRs during the different distensions with saline; CCK increased the number of TLOSRs at a mean rate of $13 \cdot 1$ compared with 9.1 with saline $(p<0 \cdot 001)$. Loxiglumide significantly decreased the number of relaxations to $5 \cdot 3$ versus $8 \cdot 3$ under paired saline infusion $(p<0 \cdot 001)$. Conclusions-In humans, CCK-A receptor subtype is involved in the occurrence of transient lower oesophageal sphincter relaxations induced by gastric distension. (Gut 1997; 40: 575-581)
\end{abstract}

Department of Gastroenterology, Hôtel-Dieu, Clermont-Ferrand, France

J Boulant

S Mathieu

A Abergel

M Dapoigny

G Bommelaer

Rotta Research Laboratorium,

Via Valosa di Sopra, 20052 Monza (MI), Italy,

M D'Amato

Correspondence to: Dr J Boulant, Department of Gastroenterology, Hôtel-Dieu, BP 69, 63003 Clermont-Ferrand, France.

Accepted for publication 23 December 1996
Keywords: lower oesophageal sphincter, transient loxiglumide.

Transient lower oesophageal sphincter relaxation (TLOSR), unrelated to swallowing, has been found to be the main mechanism of subjects and in patients with gastro-oesophageal reflux disease. ${ }^{1-6}$ Research is now directed toward identifying the mechanisms involved in the occurrence of $\operatorname{TLOSR}^{7}$ and developing drugs to decrease its rate in patients with gastro-oesophageal reflux disease.

The frequency of TLOSR is greatly increased in humans ${ }^{89}$ and dogs ${ }^{1011}$ by distension of the stomach, which probably triggers relaxations, gastro-oesophageal reflux, cholecystokinin, gastro-oesophageal reflux both in healthy gastric mechanoreceptors mainly located in the subcardiac region. ${ }^{11}$ In dogs, cholecystokinin (CCK) is involved in the occurrence of TLOSR induced by gastric distension through peripheral CCK-A receptors. ${ }^{12}$

In normal subjects, CCK-8 infusion and meals have been reported to reduce the lower oesophageal sphincter (LOS) pressure and both these effects were blocked by loxiglumide, a CCK-A receptor antagonist. ${ }^{13}$

The aim of the present study was to evaluate the role of CCK- 8 and loxiglumide in the occurrence of TLOSR induced by gastric distension in humans.

\section{Methods}

SUBJECTS

We studied 10 healthy volunteers (five women and five men; age range 25-39 years). Subjects were free of any gastrointestinal symptoms and had no history of upper gastrointestinal surgery. They did not take any medication known to alter oesophageal motor function. Each volunteer gave written consent, and the study was approved by the human ethics committee of Clermont-Ferrand Hospital, France (Comité Consultatif et de Protection des Personnes dans la Recherche Biomédicale de la Région Auvergne).

\section{MATERIALS AND MEASUREMENTS}

Oesophageal manometry was performed with a multilumen assembly incorporating a $6 \mathrm{~cm}$ sleeve device (ESM3DS Arndorfer Medical Specialities, Greendale, WI, USA). ${ }^{14}$ The sleeve sensor monitored LOS pressure. Síde hole catheters recorded pressure in the gastric fundus and oesophageal body at 5, 10, and 15 $\mathrm{cm}$ above the LOS. Another side hole detected pharyngeal pressure to monitor swallowing. Catheters were perfused with gas free distilled water by a low compliance capillary pneumohydraulic pump (Arndorfer Medical Specialities, Greendale, WI, USA). The perfusion rates were $0.1 \mathrm{ml} / \mathrm{min}$ for the pharyngeal catheter and $0.5 \mathrm{ml} / \mathrm{min}$ for the gastric and oesophageal body catheters and for the sleeve device. Output from the pressure transducers was processed by an eight channel polygraph (Polygraph HR Synectics Medical, Stockholm, 
Sweden) connected to a computer (486 DX 33, Data Jet Personal Computers).

Gastric distension was performed with air via an intragastric bag, using an electronic barostat (Institut National de la Recherche Agronomique, Toulouse, France) to maintain constant intragastric pressure by an electronic feedback mechanism. The principle of the barostat is as follows: when the stomach contracts, the barostat aspirates air from the bag to maintain constant pressure and the bag volume decreases; when the stomach is relaxed, air is injected and the bag volume increases. ${ }^{15}$ The highly compliant polyethylene bag had a maximal volume capacity of $1400 \mathrm{ml}$ and was connected to the barostat via a $12 \mathrm{~F}$ diameter single lumen polyvinyl tube. The electronic barostat was connected to the computer via the same polygraph (Polygraph HR Synectics Medical, Stockholm, Sweden).

STUDY DESIGN

Each subject fasted for at least eight hours before the study. Subjects initially underwent static oesophageal manometry to assess primary peristalsis and to determine the location of the upper oesophageal sphincter and LOS. Then the folded bag was wound round the tube and introduced slowly into the stomach through a nostril. The bag was unfolded by manually injecting $300 \mathrm{ml}$ air and pulled into the fundus, completely deflated, and connected to the barostat. The manometric probe was introduced into the oesophagus through the other nostril, the sleeve sensor being positioned in the LOS zone. A 30 minute resting recording session was then run and served as a basal control period. Thereafter the intragastric bag was inflated by stepwise $2 \mathrm{~mm} \mathrm{Hg}$ increments every five minutes until a constant pain threshold was reached. Distension steps were separated from each other by a five minute relaxation, the bag being entirely deflated. For further experiments and for each subject on each day, the constant intragastric pressure of distension was defined as $75 \%$ of the gastric pain threshold pressure. The recording was made while the subjects were seated.

The study was performed in two experiments on three separate days for each subject, involving two gastric distensions on each day (Fig 1). The two distensions at the constant pressure defined on each day were performed during 30 minutes separated by a 90 minute washout period. The gastric bag was deflated during this washout period.

In the first experiment, the effect of CCK was studied. On the same day, saline (as a control) or CCK-8s (Kinevac: sincalide; ER Squibb and Sons Ltd, Montreal, Canada ${ }^{16}$ at a dose of $30 \mathrm{ng} / \mathrm{kg} / \mathrm{h}$ were perfused in random double blind order with a syringe pump (Robomedic 100, Gazui Electronic, France) during each distension. Saline or CCK-8s infusions started 10 minutes before gastric distension and continued until the end of distension.

In the second experiment, the effect of the CCK-A receptor antagonist loxiglumide
(Rotta Research Laboratorium SpA., Monza, Italy), was studied. Due to the half life of loxiglumide (>six hours), ${ }^{17}$ it was not possible to randomise its administration against placebo on a single day. Therefore the experiment was run on two separate days, saline being perfused during the first distension as a control and loxiglumide or saline in a random double blind order (loxiglumide and saline were delivered in similar blinded ampoules) during the second distension. Infusions of loxiglumide were started 20 minutes before gastric distension with a bolus of $30 \mathrm{mg} / \mathrm{kg} / \mathrm{h}$ during 10 minutes and continued at a dose of $10 \mathrm{mg} / \mathrm{kg} / \mathrm{h}$ until the end of distension.

DATA ANALYSIS

The reader was blinded as to whether CCK, saline, or loxiglumide had been infused Manometric traces were analysed for basal LOS pressure, and for the occurrence of TLOSRs. Mean end expiratory LOS pressure was estimated with reference to gastric pressure at end expiration defined as zero.

Based on the analysis and according to Holloway et $a l,{ }^{18}$ TLOSR was defined as: (1) the absence of swallowing four seconds before and two seconds after the onset of TLOSR, (2) a relaxation rate of $1 \mathrm{~mm} \mathrm{Hg} / \mathrm{s}$, (3) time from onset to complete relaxation of 10 seconds, and (4) nadir pressure of $2 \mathrm{~mm} \mathrm{Hg}$. Excluding TLOSR associated with multiple rapid swallowing, falls in LOS pressure that fulfilled the last three criteria but had a duration $>10 \mathrm{~s}$ were also judged as TLOSR, irrespective of the timing of the onset of the fall in LOS pressure in relation to swallowing.

The maximal distension volume was reported for each distension and for each subject.

\section{STATISTICAL ANALYSIS}

Data were compared using analysis of variance (ANOVA) and Student's $t$ test for paired values. Statistical significance was accepted if $p<0 \cdot 05$. A statistical analysis of order and treatment effect was calculated. Values are presented as means (SD).

\section{Results}

OESOPHAGEAL MANOMETRY

As we always found the same LOS pressure or number of TLOSRs under saline whatever the order or day (no order effect), data obtained with CCK or loxiglumide were compared with the paired saline infusion (Fig 2).

Transient lower oesophageal sphincter relaxations Without distension, at the basal state, TLOSRs occurred at a rate of $1.4(1 \cdot 0) / 30 \mathrm{~min}$.

Gastric distension with the barostat increased the number of TLOSRs. This increase was reproducible as the number of TLOSRs under saline infusion was similar during all series of distensions with saline (Fig 2). 
Experiment 1

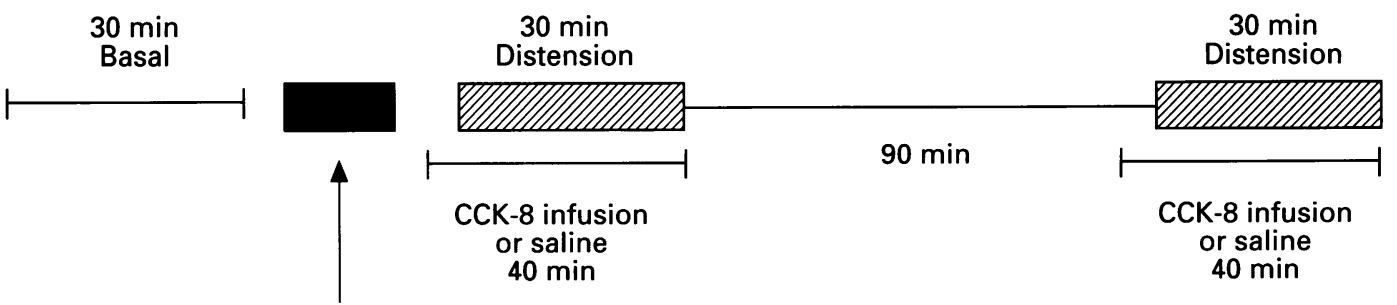

Determination of pain threshold intragastric pressure

Experiment 2 day 1

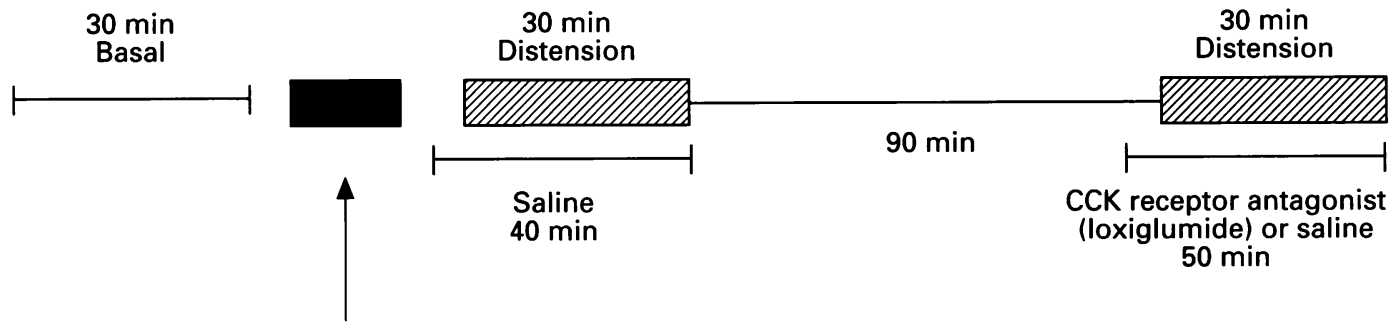

Determination of pain threshold intragastric pressure

Experiment 2 day 2

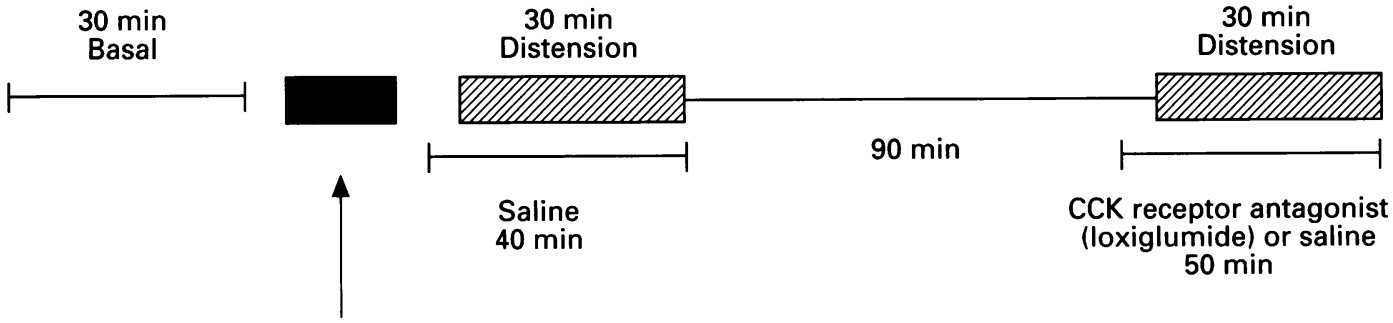

Determination of pain threshold intragastric pressure

Figure 1: Study protocol.

During the first experiment, gastric distension induced the occurrence of TLOSRs at a mean rate of $9 \cdot 1(4 \cdot 0) / 30$ min under saline infusion and $13 \cdot 1(5 \cdot 5)$ min with CCK-8 infusion ( $p<0.001$; Fig 3 ).

During the second experiment, loxiglumide infusion significantly decreased the number of TLOSRs to a mean rate of $5 \cdot 3(2 \cdot 5)$ compared with $8.3(1.7)$ under paired saline infusion $(p<0 \cdot 001 ;$ Fig 4$)$.

No significant difference was found between the mean duration of TLOSR during saline, CCK-8, or loxiglumide infusion (26.9 $(12.5) \mathrm{s}, 23.6(10.5) \mathrm{s}$, and $26.5(6.7) \mathrm{s}$ respectively).
LOS pressure

Table I shows the individual values of mean LOS pressure under gastric distension with either saline, CCK, or loxiglumide. Under saline infusion, from a basal value of 11.5 (3.0) $\mathrm{mm} \mathrm{Hg}$ before distension, the LOS pressure was significantly increased by gastric distension to mean values ranging from 13.6 (5) to $14.2(7.0) \mathrm{mm} \mathrm{Hg}(p<0.01)$ according to the various distension periods. Infusion of CCK significantly decreased the LOS pressure compared with paired saline infusion to a mean value of $8.3 \quad(5.0) \mathrm{mm} \mathrm{Hg} \quad(p<0.001)$. Loxiglumide did not significantly alter the mean resting LOS pressure after gastric 
distension, compared with saline $(11 \cdot 6(4 \cdot 0) v$ $13.6(5 \cdot 0) \mathrm{mm} \mathrm{Hg}(\mathrm{p}>0 \cdot 05)$.

\section{BAROSTAT}

\section{Intragastric pressure}

From day to day, in each subject the constant pressure chosen for distension never varied by more than $2 \mathrm{~mm} \mathrm{Hg}$, the mean being 17.5 $(0.5) \mathrm{mm} \mathrm{Hg}$.

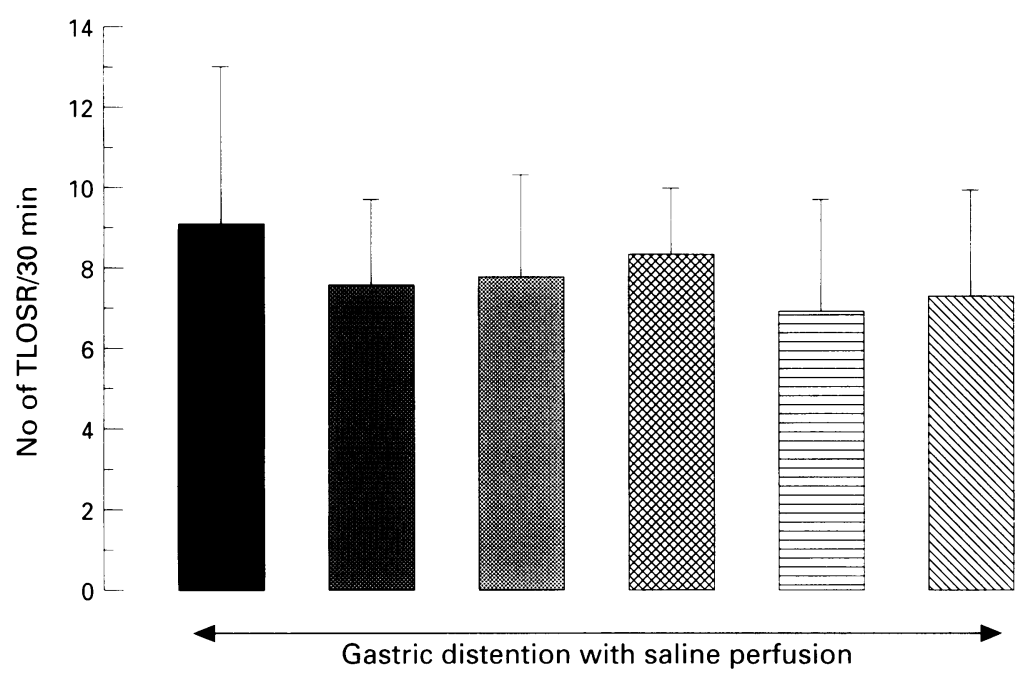

Saline first experiment, first and second distention, random with $\mathrm{CCK} ; \mathrm{n}=10$

Saline second experiment, day 1 , first distention; $n=10$

Saline second experiment, day 2, first distention; $n=10$

Saline second experiment, days 1 and 2 , first distention paired with loxiglumide; $n=10$

Saline second experiment, days 1 and 2, first distention not paired with loxiglumide; $n=10$

Saline second experiment, days 1 and 2 , second distention; $n=10$

Figure 2: All distensions with saline. There were no significant differences between these series.

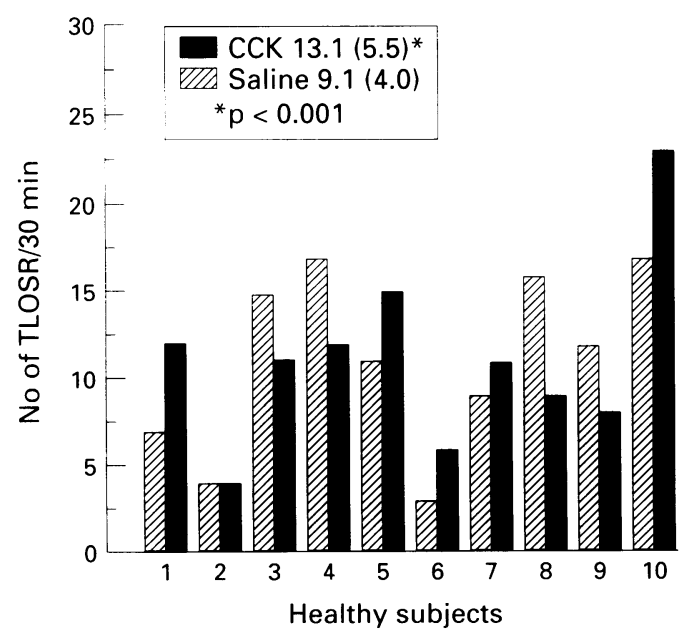

Figure 3: Number of TLOSR/30 min. Numbers in parentheses are SD. Mean data with CCK infusion compared with paired saline infusion $p<0.001$.
Intragastric distension volumes

At the constant distension pressure chosen, the average maximal value of gastric volume was significantly higher during CCK infusion (881 (235) $\mathrm{ml})$ than with saline $(763(215) \mathrm{ml})$ $(\mathrm{p}=0.001)$.

On the contrary, the average maximal volumes decreased during loxiglumide infusion (631 (185) $\mathrm{ml}$ ) compared with paired saline infusion (813 (134) ml) ( $p=0 \cdot 001$; Table II).

There was a slight but significant correlation $(r=0.4, \mathrm{p}<0.05)$ between the gastric volume and the number of TLOSRs, whatever the infusion (Fig 5).

\section{Discussion}

The results of the present study suggest that in humans gastric distension elicits TLOSRs and that endogenous $\mathrm{CCK}$ is involved via a CCK-A receptor dependent mechanism, confirming our previous findings in dogs. ${ }^{12}$

In the first part of the study, our aim was to validate a model of induction of TLOSRs in humans via gastric distension at a constant pressure as gastric gaseous distension has been found to be a potent and consistent trigger of TLOSRs in dogs. ${ }^{7} 12$ In the same way, in humans stomach distension with carbon

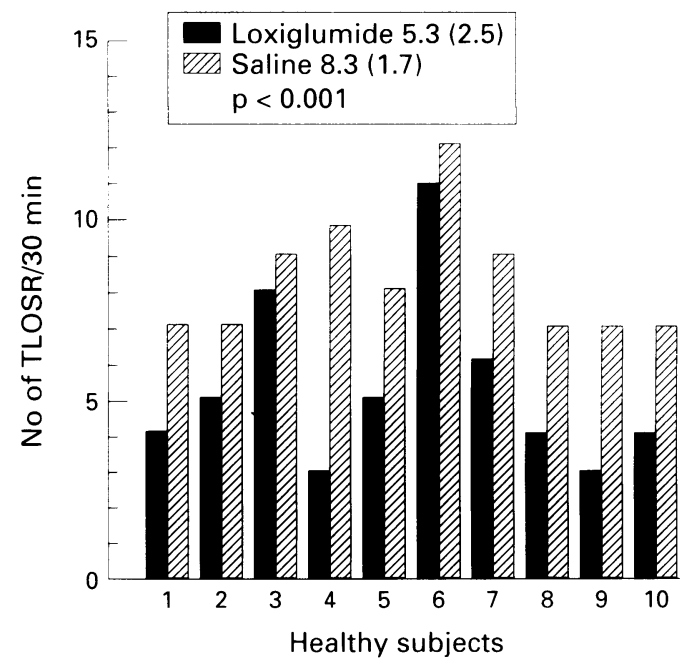

Figure 4: Number of TLOSR/30 min. Numbers in parentheses are SD. Mean data with loxiglumide infusion compared with paired saline infusion $p<0 \cdot 001$.

TABLE I LOS pressure: individual data and mean values $(S D)$ in experiments 1 and 2

\begin{tabular}{|c|c|c|c|c|}
\hline \multirow[b]{3}{*}{ Subjects } & \multicolumn{4}{|c|}{ LOS pressure $(\mathrm{mm} \mathrm{Hg})$} \\
\hline & \multicolumn{2}{|c|}{ Experiment 1} & \multicolumn{2}{|c|}{ Experiment 2} \\
\hline & Saline & $C C K$ & Saline & Loxiglumide \\
\hline 1 & $15 \cdot 2$ & $7 \cdot 6$ & $9 \cdot 1$ & $9 \cdot 1$ \\
\hline 2 & $9 \cdot 9$ & $5 \cdot 3$ & $13 \cdot 7$ & $12 \cdot 9$ \\
\hline 3 & $15 \cdot 2$ & $8 \cdot 3$ & $23 \cdot 5$ & $15 \cdot 2$ \\
\hline 4 & 9.9 & $6 \cdot 8$ & $15 \cdot 2$ & $10 \cdot 6$ \\
\hline 5 & $12 \cdot 9$ & $7 \cdot 6$ & $19 \cdot 0$ & $15 \cdot 2$ \\
\hline 6 & $15 \cdot 2$ & $6 \cdot 8$ & $18 \cdot 2$ & $19 \cdot 7$ \\
\hline 7 & $15 \cdot 2$ & $6 \cdot 1$ & $11 \cdot 4$ & $9 \cdot 9$ \\
\hline 8 & $9 \cdot 1$ & $7 \cdot 6$ & $9 \cdot 9$ & $6 \cdot 8$ \\
\hline 9 & $6 \cdot 1$ & $5 \cdot 3$ & $6 \cdot 1$ & $8 \cdot 3$ \\
\hline 10 & $33 \cdot 4$ & $22 \cdot 0$ & $9 \cdot 9$ & $8 \cdot 3$ \\
\hline Mean $(\mathrm{SD})$ & $14 \cdot 2(7)$ & $8 \cdot 3(5)^{\star}$ & $13 \cdot 6(5)$ & $11 \cdot 6(4)$ \\
\hline
\end{tabular}

${ }^{\star} \mathrm{p}<0.05 v$ paired saline 
TABLE II Intragastric distension volumes: individual data and mean values (SD) in experiments 1 and 2

\begin{tabular}{|c|c|c|c|c|}
\hline \multirow[b]{3}{*}{ Subjects } & \multicolumn{4}{|c|}{ Intragastric distension volumes ( $\mathrm{ml}$ ) } \\
\hline & \multicolumn{2}{|l|}{ Experiment 1} & \multicolumn{2}{|l|}{ Experiment 2} \\
\hline & Saline & $C C K$ & Saline & Loxiglumide \\
\hline $\begin{array}{r}1 \\
2 \\
3 \\
4 \\
5 \\
6 \\
7 \\
8 \\
9 \\
10\end{array}$ & $\begin{array}{r}500 \\
693 \\
880 \\
1005 \\
830 \\
712 \\
630 \\
980 \\
1009 \\
390\end{array}$ & $\begin{array}{r}730 \\
805 \\
960 \\
1040 \\
969 \\
869 \\
752 \\
1100 \\
1212 \\
380\end{array}$ & $\begin{array}{r}668 \\
1050 \\
850 \\
918 \\
961 \\
805 \\
628 \\
810 \\
740 \\
703\end{array}$ & $\begin{array}{l}430 \\
800 \\
450 \\
740 \\
969 \\
600 \\
460 \\
795 \\
480 \\
591\end{array}$ \\
\hline Mean (SD) & $763(215)$ & $881(235)^{\star}$ & $813(134)$ & $631(185)^{\star}$ \\
\hline
\end{tabular}

${ }^{\star} \mathrm{p}<0.05 v$ paired saline.

dioxide induced TLOSRs ${ }^{9}$ similar to relaxations associated with acid gastro-oesophageal reflux. In our dog model, ${ }^{12}$ we used an electronic barostat to maintain constant intragastric pressure during distension. With constant insufflation, an eventual action of a drug on gastric or pyloric motility may lead to changes in intragastric pressure that will indirectly modify the occurrence of TLOSRs. Moreover, in dogs gas insufflation induced a distension of the gut, discomfort, and some vomiting. Consequently, and to avoid these problems in humans we preferred to use gastric distension with a bag. Other workers have used a fatty meal as a more physiological stimulant of TLOSRs ${ }^{19}{ }^{20}$; however, this usually led to a low rate of TLOSRs, insufficient to display a possible pharmacological reduction of their occurrence rate by loxiglumide. ${ }^{19}$ Moreover, the rate of TLOSRs elicited by gastric distension was not maximal as CCK was still able to increase their number further.

To obtain a similar number of TLOSRs at either control distension, we performed at the beginning of each experiment and for each subject a stepwise increase in gastric distensions with $2 \mathrm{~mm} \mathrm{Hg}$ increments until we obtained a constant painful sensation. Then, for each subject and for all the distensions we chose a constant pressure corresponding to $75 \%$ of the pain threshold pressure. With this level of distension, we found a mean TLOSR number of eight to nine in humans, which is comparable with the mean of seven found in dogs. No significant difference was recorded from day to day concerning the pressure distensions in the same subject as defined above.

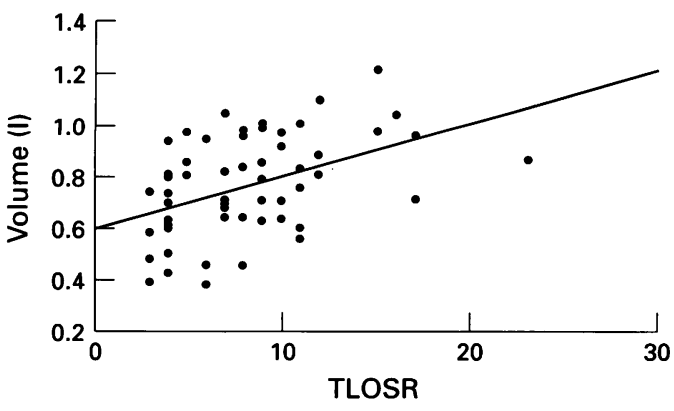

Figure 5: Correlation between distension volume and $T L O S R$ ( $r=0.4, p<0.05)$.
Neither did we obtain any significant difference in the number of TLOSRs occurring the same day between the first and the second distension with saline so no order effect interfered with our results. Moreover, this number of TLOSRs did not change between different distensions with saline from day to day. This shows the reproductibility of this model in the triggering of TLOSRs.

By contrast with a recent study ${ }^{21}$ which found that CCK-33 infusion did not affect the occurrence of TLOSR in humans, we chose CCK-8, which can be considered as a neuronal form of CCK synthesised in nerve cell bodies and released at nerve endings. ${ }^{22}$ Due to the short half life of CCK-8 (sincalide; 1.5 minutes), we were able to run the first experiment in one day with a wash out period of 90 minutes between the two distensions, and saline or sincalide was perfused in a random order. By contrast, this procedure was impossible in the second experiment due to the longer half life of loxiglumide. So we subsequently performed the second experiment on two different days on each subject with perfusion of loxiglumide only during the second distension period in a double blind random order with placebo. Sincalide was perfused at a rate of $30 \mathrm{ng} / \mathrm{kg} / \mathrm{h}$ as used medically to induce contraction of the gall bladder $^{23}$ and to induce oesophageal motility. ${ }^{13}$ Loxiglumide (CR-1505) ${ }^{24}$ is the only CCK-A antagonist available for human use. Previous studies have shown that loxiglumide given intravenously in a dose we used in our experiments, completely inhibits CCK induced effects on the gall bladder and the pancreas at physiological concentrations. ${ }^{25} 26$

The major finding of our study is the involvement of CCK receptors in the occurrence of TLOSRs induced by gastric distension in humans. This is in agreement with the postprandial release of CCK and the postprandial occurrence of TLOSRs. ${ }^{27}{ }^{28}$ The selectivity of loxiglumide for CCK-A receptors indicates that TLOSRs produced by gastric distension are mainly controlled by CCK-A receptors. Due to the lack of specific CCK-B receptor antagonists widely available for human use, we could not study the possible and partial control of CCK-B receptors. Our results did not allow us to determine whether CCK-A receptors are directly or indirectly involved in the control of TLOSRs. Neither did they enable us to differentiate between a peripheral or central location of the CCK subtypes of receptors involved in the control of TLOSRs. Nevertheless, according to our results on dogs, we speculate that those receptors would be peripheral. ${ }^{12}$ Their location on vagal afferent fibres can be postulated as CCK has been found to activate these fibres, ${ }^{29}$ and as CCK binding sites have been shown in the cervical $^{30}$ and subdiaphragmatic vagus nerve. ${ }^{31}$ Moreover, our results suggest that gastric distension could trigger TLOSRs via stimulation of stretch fundic receptors as the number of TLOSRs paralleled the variation of gastric volumes, whatever the drug used. A neuronal or muscular location of the CCK-A 
receptors cannot be distinguished from our results.

In this study, fundic distension induced a small but significant increase in resting LOS pressure as already found in dogs and in humans with such distension volumes. ${ }^{8} 1112$ Infusion of CCK-8 induced a reduction in LOS pressure in humans. ${ }^{13213235}$ However, under our experimental conditions, loxiglumide did not modify the resting LOS pressure under gastric distension. It is worth noting that our subjects were sitting, which is not the usual position for studying LOS pressure. Moreover the increase in LOS pressure afforded by the gastric distension could preclude a further effect of loxiglumide. On the other hand, our results do not conflict with those obtained in dogs, in which only CCK-B and not CCK-A receptors controlled the resting LOS pressure under gastric distension. ${ }^{12}$ Several authors have shown the inhibitory effect of a CCK-A receptor antagonist on the decrease of the basal LOS pressure induced by CCK infusion, ${ }^{13}$ oral ingestion of cholestyramine, ${ }^{36}$ or a fatty meal ${ }^{19}$ in humans. These results, taken together, allow us to speculate that, in humans, as in dogs, CCK-B receptors might play a part in the reflex involved in the increase in LOS pressure induced by gastric distension whereas CCK-A receptors are involved in the control of LOS pressure under endogenous release or infusion of CCK. However, the aim of our study with this model was not to evaluate the effect of $\mathrm{CCK}$ or CCK receptor antagonists on basal LOS pressure.

The finding that loxiglumide inhibits TLOSRs induced by gastric distension may have clinical implications as TLOSR is regarded as the main mechanism responsible for gastro-oesophageal reflux in healthy humans as well as patients with gastrooesophageal reflux disease. It has been proposed that manipulating the afferent pathway, either peripherally or within the CNS, that controls and mediates TLOSRs would be the best way of targeting a pharmacological approach of the problem. ${ }^{37}$ Whether CCK antagonists will prove to be useful agents in reducing the frequency of TLOSR in reflux disease awaits further studies.

We thank Dr Pierre Poitras for technical assistance. This work was supported by Jouveinal Laboratories and IRMAD (Astra, France). This work was presented in part at the XV International Symposium of Gastrointestinal Motility, Rome, Italy, November 1995 and at the AGA meeting, San Francisco, May 1996.

1 Dent J, Dodds WJ, Friedman RH, Sekiguchi T, Hogan WJ, Arndorfer RC, Petrie DJ. Mechanism of gastroesophageal reflux in recumbent asymptomatic human subjects. $\mathcal{f}$ Clin Invest 1980; 65: 256-67.

2 Dodds WJ, Dent J, Hogan WJ, Helm JF, Hauser R, Pate GK. Mechanisms of gastroesophageal reflux in patients with reflux esophagitis. $N$ Engl $\mathcal{F}$ Med 1982; 307: 1547-52.

3 Mittal RK, McCallum RW. Characteristics of transient lower esophageal sphincter relaxation in humans. $A m f$ Physiol 1987; 252: G636-41.

4 Dent J, Holloway RH, Toouli J, Dodds WJ. Mechanisms of lower oesophageal sphincter incompetence in patients with symptomatic gastro-oesophageal reflux. Gut 1988 ; 29: $1020-8$.

5 Mittal RK, McCallum RW. Characteristics and frequency of transient relaxations of the lower esophageal sphincter in patients with reflux esophagitis. Gastroenterology 1988; 95: 593-9.

6 Schoeman MN, Tippett MD, Akkermans LMA, Dent J, Holloway RH. Mechanisms of gastroesophageal reflux in ambulant healthy human subjects. Gastroenterology 1995 108: 83-91.

7 Martin CJ, Patrikios J, Dent J. Abolition of gas reflux and transient lower esophageal sphincter relaxation by vagal blockade in the dog. Gastroenterology 1986; 91: 890-6.

8 Holloway RH, Hongo M, Berger K, McCallum RW Gastric distension: a mechanism for postprandial Gastric distension: a mechanism for postprandial gastroeso

9 Wyman JB, Dent J, Heddle R, Dodds WJ, Toouli J, Downton J. Control of belching by the lower oesophageal sphincter. Gut 1990; 31: 639-46.

0 Patrikios J, Martin CJ, Dent J. Relationship of transient lower esophageal sphincter relaxation to postprandial gastroesophageal reflux and belching in dogs. Gastroenterology 1986; 90: 545-51.

11 Franzi SJ, Martin CJ, Cox MR, Dent J. Response of canine lower esophageal sphincter to gastric distension. $A m \mathcal{F}$ Physiol 1990; 259: G380-5.

12 Boulant J, Fioramonti J, Dapoigny $M$, Bommelaer G, Bueno L. Cholecystokinin and nitric oxide in transient lower esophageal sphincter relaxation to gastric distension lower esophageal sphincter relaxation to gastric

13 Katschinski M, Schirra J, Koppelberg T, Arnold R, Rovati LC, Beglinger C, Adler G. Effect of cholecystokininA-receptor blockade on oesophageal motility. Eur $\mathcal{F}$ Gastroenterol Hepatol 1994; 6: 983-9.

14 Dent J. A new technique for continuous sphincter pressure measurement. Gastroenterology 1976; 71: 263-7.

15 Ropert A, Bruley Des Varannes S, Bizais Y, Rozé C, Galmiche JP. Simultaneous assessment of liquid emptying and proximal gastric tone in humans. Gastroenterology 1993; 105: $667-74$

16 Byrnes DJ, Borody T, Daskalopoulos G, Boyle M, Benn I. Cholecystokinin and gallbladder contraction: effect of CCK infusion. Peptides 1981; 2: 259-62.

17 Setnikar I, Chisté R, Makovec F, Rovati LC, Warrington SJ Pharmacokinetics of loxiglumide after single intravenous or oral doses in man. Arzneim Forsch 1988; 38: 716-20.

18 Holloway RH, Penagini R, Ireland AC. Criteria for objective definition of transient lower esophageal sphincter relaxation. Am f Physiol 1995; 31: G128-33.

19 Trudgill N, D'Amato M, Riley S. Effects of loxiglumide on lower oesophageal sphincter function following a fat meal in healthy volunteers [abstract]. Gut 1996; 38 (suppl 1): A168.

20 Mittal RK, Holloway R, Dent J. Effect of atropine on the frequency of reflux and transient lower esophageal frequency of reflux and transient lower esophageal
sphincter relaxation in normal subjects. Gastroenterology sphincter relaxation in

21 Ledeboer M, Masclee AAM, Baatstra MR, Jansen JBMJ, Lamers CBHW. Effect of cholecystokinin on lower oesophageal sphincter pressure and transient lower oesophageal sphincter relaxations in humans. Gut 1995; 36: $39-44$

22 Dockray GJ, Gregory RA, Tracy HJ, Zhu WY. Transport of cholecystokinin-octapeptide-like immunoreactivity toward the gut in afferent vagal fibres in cat and dog. 7 Physiol (Lond) 1981; 314: 501-11.

23 Meyer BM, Werth BA, Beglinger C, Hildebrand P, Jansen JBMJ, Zach D, et al. Role of cholecystokinin in regulation of gastrointestinal motor functions. Lancet 1989; ii: of gastr.

24 Setnikar I, Bani M, Cereda R, Chisté R, Makovec F, Pacini $\mathrm{MA}$, et al. Pharmacological characterisation of a new potent specific non-polypeptidic cholecystokinin antagonist. Arzneimittelforschung 1987; 37: 703-07.

25 Schmidt WE, Creutzfelt W, Schleser A, Choudhury AR, Nustede R, Hocker M, et al. Role of CCK in regulation of pancreaticobiliary functions and GI motility in humans: effects of loxiglumide. Am $\mathcal{F}$ Physiol 1991; 260: G197-206.

26 Hildebrand P, Beglinger C, Gyr K, Jansen JBMJ, Rovati LC, Zuercher M, et al. Effects of a cholecystokinin receptor antagonist on intestinal phase of pancreatic and biliary responses in man. $\mathcal{F}$ Clin Invest 1990; 85: 640-6.

27 Penagini R, Bartesaghi B, Conte D, Bianchi P. Rate of transient lower oesophageal sphincter relaxations of healthy humans after eating a mixed nutrient meal: time healthy humans after eating a mixed nutrient meal: time
course and comparison with fasting. Eur $\mathcal{f}$ Gastroenterol course and comparison
Hepatol 1992; 4: 35-8.

28 Holloway RH, Kocyan P, Dent J. Provocation of transient lower esophageal sphincter relaxations by meals in patients with symptomatic gastroesophageal reflux. Dig Dis Sci 1991; 36: 1034-9.

29 Blackshaw LA, Grundy D. Effects of cholecystokinin (CCK-8) on two classes of gastroduodenal vagal afferent fibre. ₹ Auton Nerv Syst 1990; 31: 191-202.

30 Zarbin MA, Wamsley JK, Innis RB, Kuhar MJ. Cholecystokinin receptors: presence and axonal flow in rat vagus nerve. Life Sci 1981; 29: 697-705.

31 Norgren R, Smith GP. Central distribution of subdiaphragmaic vagal branches in the rats. $f$ Comp Neurol 1988; 237: 207-23.

32 Resin H, Stern DH, Sturdevant RAL, Isenberg JI. Effect of the C-terminal octapeptide of cholecystokinin on lower esophageal sphincter pressure in man. Gastroenterology 1973; 64: 946-9.

33 Fisher RS, DiMarino AJ, Cohen S. Mechanism of cholecystokinin inhibition of lower esophageal sphincter pressure. Am f Physiol 1975; 228: 1469-73. 
34 Dodds WJ, Dent J, Hogan WJ, Patel GK, Toouli J, Arndorfer RC. Paradoxical lower esophageal sphincter contraction induced by cholecystokinin-octapeptide in patients with achalasia. Gastroenterology $1981 ; 80: 327-33$.

35 Ujiie $\mathrm{H}$, Hongo $\mathrm{M}$, Okuno $\mathrm{Y}$, Nishimura $\mathrm{N}$, Ueno $\mathrm{M}$ Toyota $T$. Effect of caerulein on LES function in normal subjects and achalasia patients. Gastroenterology 1990; 98: A398.
36 Masclee AAM, Jansen JBMJ, Rovati LC, Lamers CBHW. Effect of cholestyramine and cholecystokinin receptor antagonist CR1505 (Loxiglumide) on lower esophageal sphincter pressure in man. Dig Dis Sci 1993; 38: 1889-92.

37 Mittal RK, Holloway RH, Penagini R, Blackshaw LA, Dent J. Transient lower esophageal sphincter relaxation. Gastroemterology 1995; 109: 601-10. 